\title{
MONOTONICITY OF SEQUENCES INVOLVING GEOMETRIC MEANS OF POSITIVE SEQUENCES WITH MONOTONICITY AND LOGARITHMICAL CONVEXITY
}

\author{
BAI-Ni GUO AND FENG QI
}

Abstract. Let $f$ be a positive function such that $x[f(x+1) / f(x)-1]$ is increasing on $[1, \infty)$, then the sequence $\left\{\sqrt[n]{\prod_{i=1}^{n} f(i)} / f(n+1)\right\}_{n=1}^{\infty}$ is decreasing. If $f$ is a logarithmically concave and positive function defined on $[1, \infty)$, then the sequence $\left\{\sqrt[n]{\prod_{i=1}^{n} f(i)} / \sqrt{f(n)}\right\}_{n=1}^{\infty}$ is increasing. As consequences of these monotonicities, the lower and upper bounds for the ratio $\sqrt[n]{\prod_{i=k+1}^{n+k} f(i)} / \sqrt[n+m]{\prod_{i=k+1}^{n+k+m} f(i)}$ are obtained, where $k$ is a nonnegative integer and $m$ a natural number. Some applications are given.

Mathematics subject classification (2000): 05A10, 26D15, 26E60, 26A48, 33B15.

Key words and phrases: monotonicity, inequality, geometric mean, ratio, positive sequence, logarithmically concave, mathematical induction.

\section{REFERENCES}

[1] H. Alzer, On an inequality of H. Minc and L. Sathre, J. Math. Anal. Appl., 179, (1993), 396-402.

[2] B.-N. GUO, F. QI, Inequalities and monotonicity for the ratio of gamma functions, Taiwanese J. Math., 7, 2 (2003), 239-247.

[3] T. H. Chan, P. GaO AND F. QI, On a generalization of Martins' inequality, Monatsh. Math., 138, 3 (2003), 179-187. RGMIA Res. Rep. Coll., 4, 1 (2001), Art. 12, 93-101. Available online at URL: http://rgmia.vu.edu.au/v4n1.html.

[4] Ch.-P. Chen, F. QI, P. CERone, And S. S. Dragomir, Monotonicity of sequences involving convex and concave functions, Math. Inequal. Appl. 6, 2 (2003), 229-239. RGMIA Res. Rep. Coll., 5, 1 (2002), Art. 1, 3-13. Available online at URL: http: //rgmia.vu. edu.au/v5n1.html.

[5] D. Kershaw, A. LAforgia, Monotonicity results for the gamma function, Atti Accad. Sci. Torino Cl. Sci. Fis. Mat. Natur., 119, (1985), 127-133.

[6] J.-CH. KuANG, Some extensions and refinements of Minc-Sathre inequality, Math. Gaz., 83, (1999), 123-127.

[7] H. Minc, L. SATHRE, Some inequalities involving $(r !)^{1 / r}$, Proc. Edinburgh Math. Soc., 14, (1964/65), 41-46.

[8] J. Pečarić, F. Proschan, And Y. L. Tong, Convex Functions, Partial Orderings, and Statistical Applications, Mathematics in Science and Engineering, 187, Academic Press, 1992.

[9] F. QI, An algebraic inequality, J. Inequal. Pure Appl. Math., 2, 1 (2001), Art. 13. Available online at URL: http: / /jipam.vu.edu.au/article.php?sid=129. RGMIA Res. Rep. Coll., 2, 1 (1999), Art. 8,81-83. Available online at URL: http: //rgmia.vu.edu.au/v2n1.html.

[10] F. QI, Generalization of H. Alzer's inequality, J. Math. Anal. Appl., 240, (1999), 294-297.

[11] F. QI, Inequalities and monotonicity of sequences involving $\sqrt[n]{(n+k) ! / k !}$, Soochow J. Math., 29, 4 (2004), 353-361. RGMIA Res. Rep. Coll., 2, 5 (1999), Art. 8, 685-692. Available online at URL: http://rgmia.vu.edu.au/v2n5.html. 
[12] F. QI, Inequalities and monotonicity of the ratio for the geometric means of a positive arithmetic sequence with unit difference, Internat. J. Math. Ed. Sci. Tech., 34, 4 (2003), 601-607. Austral. Math. Soc. Gaz., 30, 3 (2003), 142-147. RGMIA Res. Rep. Coll., 6, (2003), suppl., Art. 2. Available online at URL: http://rgmia.vu.edu .au/v6 (E) .html.

[13] B.-N. GUO, F. QI, Inequalities and monotonicity of the ratio for the geometric means of a positive arithmetic sequence with arbitrary difference, Tamkang. J. Math., 34, 3 (2003), 261-270.

[14] F. QI, On a new generalization of Martins' inequality, RGMIA Res. Rep. Coll., 5, 3 (2002), Art. 13, 527-538. Available online at URL: http://rgmia.vu.edu.au/v5n3.html.

[15] F. QI, B.-N. GuO, An inequality between ratio of the extended logarithmic means and ratio of the exponential means, Taiwanese J. Math., 7, 2 (2003), 229-237. RGMIA Res. Rep. Coll., 4, 1 (2001), Art. 8, 55-61. Available online at URL: http://rgmia.vu.edu.au/v4n1.html.

[16] F. QI, B.-N. GUO, Monotonicity of sequences involving convex function and sequence, Math. Inequal. Appl. (2006), in press. RGMIA Res. Rep. Coll., 3, 2 (2000), Art. 14, 321-329. Available online at URL: http://rgmia.vu.edu.au/v3n2.html.

[17] F. QI, B.-N. GUO, Monotonicity of sequences involving geometric means of positive sequences with logarithmical convexity, RGMIA Res. Rep. Coll., 5, 3 (2002), Art. 10, 497-507. Available online at URL: http://rgmia.vu.edu.au/v5n3.html.

[18] F. QI, B.-N. GUO, Some inequalities involving the geometric mean of natural numbers and the ratio of gamma functions, RGMIA Res. Rep. Coll., 4, 1 (2001), Art. 6, 41-48. Available online at URL: http://rgmia.vu.edu.au/v4n1.html.

[19] F. QI, Q.-M. LuO, Generalization of H. Minc and J. Sathre's inequality, Tamkang J. Math., 31, 2 (2000), 145-148. RGMIA Res. Rep. Coll., 2, 6 (1999), Art. 14, 909-912. Available online at URL: http://rgmia.vu.edu.au/v2n6.html.

[20] F. QI, N. TOWGHI, Inequalities for the ratios of the mean values of functions, Nonlinear Funct. Anal. Appl., 9, 1 (2004), 15-23. An inequality for the ratios of the arithmetic means of functions with a positive parameter, RGMIA Res. Rep. Coll., 4, 2 (2001), Art. 15, 305-309. Available online at URL: http: //rgmia.vu.edu.au/v4n2.html.

[21] J. A. SAmpaio Martins, Inequalities of Rado-Popoviciu type, In: Marques de Sá, Eduardo (ed.) et al. Mathematical studies. Homage to Professor Doctor Luís de Albuquerque. Coimbra: Universidade de Coimbra, Faculdade de Ciências e Tecnologia, Departamento de Matemática, 169-175 (1994).

[22] J. SÁNDOR, On the gamma function, I-III, Publ. C. R. M. P. Neuchâtel, Série 1, 21, (1989), 4-7; Série 1, 28, (1997), 10-12; Série 2, 19 (2001), 33-40. 